Cahiers $d u$ MONDE RUSSE

\section{Cahiers du monde russe}

Russie - Empire russe - Union soviétique et États indépendants

$49 / 4 \mid 2008$

Destins individuels et terreur. Jeunesse dans la société post-stalinienne

\title{
The soslovie (estate) paradigm
}

Reflections on some open questions

\section{Michael Confino}

\section{CpenEdition}

\section{Journals}

Édition électronique

URL : https://journals.openedition.org/monderusse/9502

DOI : $10.4000 /$ monderusse. 9502

ISSN : $1777-5388$

Éditeur

Éditions de l'EHESS

Édition imprimée

Date de publication : 28 décembre 2008

Pagination : 681-704

ISBN : 978-2-7132-2197-2

ISSN : $1252-6576$

Référence électronique

Michael Confino, "The soslovie (estate) paradigm », Cahiers du monde russe [En ligne], 49/4 | 2008,

mis en ligne le 01 janvier 2008, consulté le 04 septembre 2022. URL : http://journals.openedition.org/ monderusse/9502 ; DOI : https://doi.org/10.4000/monderusse.9502 
[Nous remercions Michael Confino d'avoir choisi les Cahiers du Monde russe pour publier son essai sur les soslovija (états) comme système de classification sociojuridique. Dans le prochain numéro, une contribution d'Elise Kimerling Wirtschafter fera écho à cet article. Nous souhaitons que le débat ainsi amorcé soit prolongé par la publication de nouvelles contributions et invitons ceux qui désireraient participer à cette discussion à nous soumettre leurs propositions. (NdlR)]

\author{
MICHAEL CONFINO
}

\title{
THE SOSLOVIE(ESTATE) PARADIGM
}

\author{
Reflections on some open questions
}

\section{Preliminary remarks}

The question of the structure and evolution of imperial Russian society has remained on the scholarly research agenda because of the contingent encounter of two reasons. One stems from the issues raised by the withering away of old concepts and the emergence of new approaches in historical writing; another, because of the impression that well-defined concepts need elucidation. As in other fields in Russian historiography, the major event which invited a reconsideration of such well established beliefs was the collapse of the "1917 paradigm" after the fall of the Soviet Union, a reconsideration which in fact began in the second half of the 1980s, since Gorbachev's policies gave implicitly a push to a perestroika in historical thinking, too, for historians in Russia as well as in the West. ${ }^{1}$

The historiography of the character of Russian society after the 1860 s saw as one of its tasks to pinpoint the main trends of the society's evolution in an attempt to project the possible directions of its development after 1914 and after 1917 if there was no war, a subject to which several publications of Leopold Haimson have contributed to put on the scholarly agenda. ${ }^{2}$ The purpose of this essay is more

1. See Michael Confino, "Present Events and the Representation of the Past. Some Current Problems in Russian Historical Writing," Cahiers du Monde russe, 35, 4 (October-December 1994): 839-868.

2. See Leopold H. Haimson, "The Problem of Social Stability in Urban Russia, 1905-1917," Slavic Review, (part 1) 23, 4 (December 1964): 619-642, and (part 2) 24, 1 (March 1965): 1-22, with comments by Arthur Mendel, Theodore von Laue, and Haimson's Reply. See also George L. Yaney, "Social Stability in Prerevolutionary Russia: A Critical Note," Slavic Review, 24, 3 (September 1965): 521-527; Alfred Levin, "More on Social Stability, 1905-1907," Slavic Review, 35, 1 (March 1966): 149-154; Arthur Mendel, "On Interpreting the Fate of Imperial Russia," in Theofanis George Stavrou, ed., Russia under the Last Tsar (Minneapolis: University of Minnesota Press, 1969), 13-41. See also L.H. Haimson, "“The Problem of Political 
limited, and it will focus on only one institution of that society: the estates (sosloviia or sostoianiia). The topic is not new, perhaps the questions it may elicit are. What is the relationship between sosloviia and social groups? Does the existence of sosloviia exclude the existence of social groups? If it does, then what type of society existed in pre-revolutionary Russia? If the existence of sosloviia does not exclude the presence of social groups within the global society, then how these groups fit in it; how they interact upon each other; and how they position themselves with regard to the major social, economic, and political issues of their time? These questions amount to discussing the whole range of topics related to the structure and dynamics of Russian pre-revolutionary society. The intention of this short essay is neither to do that, nor to reject existing interpretations, but to formulate some new hypotheses, and to check the usefulness of the soslovie paradigm in the analysis of Old Russia's society.

One of the initial assumptions of this short article is that a society did exist in imperial Russia, and that it was not obliterated by the State in the reality of things. It should not be considered therefore as non-existent, as often implied in some historians' descriptions, who posit that the groups or strata (of whatever kind) within the global society were estranged and alienated from each other, fragmented, and isolated, in addition to the perennial (and hollow) "divorce between state and society." If such a pervasive alienation did exist, it would have signified that there were no social relations between the groups, and if there were no such relations, then there would have been no society, and therefore nothing to speak and write about.

\section{A short history of interpretations}

Conventional interpretations acknowledge the existence of two major models regarding the type of society in the Old Regime. The classic Marxist view holds that the society of the Old Regime was based on classes and was a class society. Thus, typically, it would include a ruling class of the exploiters and the mass of the exploited by their masters: slave owners and slaves, or feudal landlords and unfree peasants. At a later stage of economic development, the rising bourgeoisie and the working class would emerge within this bipolar social configuration.

But even in this simple summary of a very complex process, there are already several difficulties. The first is, were the peasants a class? According to Marxist theory they were not, and in terms of social formations they are considered as a composite stratum (prosloika; strate in French). Following Ricardo, Marx

and Social Stability in Urban Russia on the Eve of War and Revolution' Revisited," Slavic Review, 59, 4 (Winter 2000): 848-875; and for a synthesis integrating the major trends and institutions of the Old Regime see Marc Raeff, Comprendre l'Ancien Régime en Russie: État et société en Russie impériale. Essai d'interprétation, with a preface by Alain Besançon (P.: Éditions du Seuil, 1982). 
repeatedly acknowledged the existence of three classes in modern society: wage laborers, capitalists, and landowners. ${ }^{3}$ The peasantry was not a class, but only a disparate assemblage of various producers, agricultural laborers, craftsmen, and men of all jobs, regardless of Marx's contempt for what he termed "the idiocy of rural life," about which he knew next to nothing. But if this were so, then was the Old Regime a one-class society? And if it was a one-class society, how did the class struggle take place in such an amputated social formation? ${ }^{4}$ Whatever the answers to these questions, the Marxist stand focuses basically on the economic position in the process in production and the economic relations of the groups described.

The second model is Roland Mousnier's notion (and its different variants) that the Old Regime had a society based on orders (or estates, but Mousnier explicitly prefers the term "orders"). In his view, this is a society of orders and has no classes; the orders are "legal formations" (entités juridiques; iuridicheskie gruppy) based on the following criteria: dignity (honor), power, consideration (social esteem). Although from a certain angle Mousnier's thesis may remind of the Mafia's hierarchical ethos, it is, sociologically speaking, a model reflecting social status, stemming chiefly from the military function of most of the high orders' members. In other words, the society-of-orders model represents a structure of status.

With regard to the Old Regime in Russia, usual interpretations in Western historiography consider that the sosloviia were formed in the eighteenth century, in contrast to the Western European estates which appeared much earlier. Another opinion holds that the sosloviia lacked the corporate vitality characteristic of the European estates, and that the Russian sosloviia did not develop as "genuine estates" or were abortive as "genuine estates." In addition, according to this view, the sosloviia retarded the social and economic development of the country by arresting the natural process of change and growth. It was only the gradual emancipation of society from bureaucratic controls and from decaying estates that permitted more dynamic growth in the second half of the nineteenth century.

This process accelerated steadily from the time of the Great Reforms in the 1860s, which began to dismantle the estate structure and unleashed the transformation of the sosloviia into classes. In other words, in Russia the classes emerged out of the sosloviia, and the process was one of a soslovnoe obshchestvo turning into a society of classes. ${ }^{6}$ As Haimson succinctly put it: "Russia evolved

3. See for instance, Karl Marx, Capital: A Critique of Political Economy (M.: Foreign Languages Publishing House, 1962), vol. III, 862; see also Peter Calvert, The Concept of Class: An Historical Introduction (New York: St. Martin's Press, 1982), 67.

4. This question is examined below in Section IV of the essay.

5. Among others, this opinion is held, for instance, by Marc Raeff and Alfred Rieber, as we will see below.

6. This view can be found, for instance, in the works of Jerome Blum, Leopold Haimson, Neil Weissman, François-Xavier Coquin, and Thomas Owen. Elise Kimerling Wirtschafter holds that the Muscovite chin evolved into the imperial soslovie, which turned into the late imperial class. 
from a society of sosloviia into a class society." In this light, it would appear that Western interpretations follow the Mousnier model in that the Old Regime was a society of orders (although described by some scholars as "imperfect orders" in Russia), and the "class society" emerged after it, as the classes evolved out of the estates. (This sort of class formation is consistent with Mousnier's model since he rejects the existence of classes only under the Old Regime.)

There are also other opinions. Alfred Rieber holds that the Old Regime society was a soslovnoe obshchestvo, but, unlike Haimson, he thinks that it could not evolve into a class society as this happened in the West, and the main reason for this deficiency - this Russian version of a Sonderweg - was the imperfect nature of the sosloviia, in Rieber's words: “[...] sosloviia in Russia lacked the essential ingredients for the development of corporate rights and self-consciousness. Unlike Western Europe, Russia had not properly laid the foundation upon which to construct a genuine class society."8 This interpretation has a high degree of consistency and internal logic, for it means that a lack of genuine estates is what generated the lack of genuine social classes. In this view, Russian society in the time of the estates as well as in the era of the classes, was therefore a society sui generis. But philosophically and sociologically speaking, sui generis entities are non-comparable to any other, and if this were so, then how can we analyze the nature and structure of this society, and should we invent a new taxonomy and a new vocabulary to do it?

Another interpretation that caught the historians' attention was Gregory Freeze's well researched inquiry "The Soslovie (Estate) Paradigm in Russian Social History." Freeze writes at the beginning of his article that "the modern notion of soslovie arose only in the early nineteenth century," 10 and not in the eighteenth century as usually assumed, that "the estate system was dynamic and still actively developing" (and not disintegrating) in the nineteenth century, and that "the resilience of this social order contravenes the customary assumption of an inexorable transition from estate to class in post-reform and revolutionary Russia."11 This last statement needs elucidation since it may lead to believe that Freeze is arguing against "the customary assumption of an inexorable transition from estate to class." Actually this is not what Freeze wants to demonstrate. As he says in the conclusion of the same article: "Sosloviia did not inexorably dissolve

7. L.H. Haimson, "Conclusion: Observations on the Politics of the Russian Countryside (190514)," in L.H. Haimson, ed., The Politics of Rural Russia, 1905-1914 (Bloomington: Indiana University Press, 1979), 276; see also Seymour Becker, Nobility and Privilege in Late Imperial Russia (DeKalb: Northern Illinois University Press, 1985), 170.

8. Alfred J. Rieber, Merchants and Entrepreneurs in Imperial Russia (Chapel Hill: University of North Carolina Press, 1982), 416; see also Alfred Rieber, "The Sedimentary Society," Russian History, 16, 2-4 (1989): 353-376.

9. Gregory L. Freeze, “The Soslovie (Estate) Paradigm and Russian social History," American Historical Review, 91, 1 (February 1986): 11-36.

10. Freeze, “The Soslovie Paradigm," 14.

11. Ibid. 
into classes in the post-reform era, as traditionally posited in the estate-class paradigm. What did emerge, however, was a "complex, polymorphic social structure - a 'mixed system' of estates and classes." 12 In other words, a system in which classes coexisted along the old estates. But this view is not very different from what Freeze calls "the traditionally posited estate-class paradigm." To the best of my knowledge, no scholar has argued that the estates disappeared overnight, and that the classes emerged from tabula rasa.

The notion of "a mixed system of estates and classes" proposed by Freeze is an interesting but not entirely new one. It had already been used by members of the United Nobility (for instance, by F.D. Samarin in 1907 in a speech at the Fourth Council of the United Nobility.) And there are similarities between this "mixed system" and other concepts formulated by scholars in the past. One of them is the concept of mnogoukladnost' (multi-layeredness; plurality of economic and social structures) elaborated by Mikhail Ja. Gefter, Konstantin N. Taranovskii, Pavel V. Volobuev, and other non-orthodox Soviet scholars in the 1960s; another is the description of this period as a transitional one, and therefore a mixed one, offered by several Western and Soviet historians.

Freeze's intention was not only to present a new view of the "soslovie paradigm," but also, as he writes, to "have argued for a fundamental reconceptualization of prerevolutionary social history." 13 This does not seem to have happened, and the really novel element in Gregory Freeze's thesis remains the view, often quoted, but rarely adopted, that at the beginning of the twentieth century the sosloviia were not in decline, but on the contrary - on the rise and flourishing.

\section{Wrestling with taxonomies}

A number of historians in Russia still follow amended versions of the Soviet model which may schematically be summarized as follows. First, it considers the estates as an intrinsic part of the "feudal society" which lasted in Russia from the ninth century to 1861 , the year of the abolition of serfdom. After that date there remained lingering survivals (perezhitki) of the estates. Second, given the assumptions of Leninist historiography, the Soviet historians felt uneasy to use a juridical term (soslovie) in a class analysis of society; consequently, they settled for a composite term - klasssoslovie - believing that it subsumes the social and economic substructure; but this would have been so in only two cases: if the legal notion of soslovie was entirely overlapping with the sociological formation of class (which it was not), or if both terms had no specific taxonomic content (which would have made the whole discussion an exercise in futility). But regarding the period 1861-1917, the Soviet historians' opinion was in fact that there existed not an evolution from sosloviia to

12. Ibid., 36.

13. Ibid., 35 . 
classes as they asserted, but rather from klassy-sosloviia to classes. However, even this corrected stand does not solve one major problem. According to Lenin, even in capitalist Russia and after 1900, the peasantry was a feudal class-soslovie: "The peasantry still remains a class, precisely a class not of the capitalist society, but of the feudal society," 14 and in fact this means that, in his view, the peasantry was a klasssoslovie. But if so, this utterance hints also that Marxist doctrine does not know what to do with the peasantry in its social class analysis. For that reason some Western neo-Marxists have spoken of "the embarrassment of the peasantry" in Marxist doctrine. "Embarrassment," because Lenin's statement raises also the question: is the Marxist definition of "class" different in feudal society and in capitalist society? Whatever the theoretical outcome of this "embarrassment," it seems clear that the klass-soslovie juxtaposition does not solve the major problem of social analysis in this subject.

Other concepts, intended to overcome this kind of deficiencies, and devised to define the relationship between "estate" and "class" on a more solid theoretical basis, have also encountered difficulties. Thus, speaking of the nobility, Gary Hamburg observed that "both Western and Soviet scholars have tended to use the legal term $d$ vorianskoe soslovie (noble Estate) as a synonym of $d$ vorianskii klass (noble class). This easy equation ignores a distinction made by Marx himself between Stand (Estate) and Klass [...]"15 Although, as we shall see, the "distinction" that Marx did or did not make is not very helpful in this case, the tendency of Western and Russian scholars to equate estates and classes is symptomatic of the theoretical uncertainty and ambiguity that reigns in this topic.

This ambiguity generates at times dissatisfaction and attempts to overcome it by ignoring the theoretical aspect of the subject altogether. Thus, in the Index of Vladimir Andrle's book, A Social History of Twentieth-Century Russia, it is said "soslovie, see social estates," and "sostoianie, see social estates." And in the text of the book both soslovie and sostoianie are equated with "social estates."16 One wonders, with regard to the nobility for instance, what kind of "social estate" was that in which were included the wealthy magnates who owned huge tracks of land and (before 1861) thousands of serfs, and, on the other hand, the poor provincial gentry who had less than 10 serfs and lived like their peasants. Similarly, the

14. M.T. Beliavskii, "Klassy i sosloviia feodal’nogo obshchestva v Rossii v svete leninskogo naslediia," [Classes and estates in the feudal society in the light of Lenin's legacy] Vestnik Moskovskogo Universiteta, no. 2 (1970): 78; see also A.A. Preobrazhenskii, "Ob evoliutsii klassovogo-soslovnogo stroia v Rossii," [On the evolution of class-estates regime in Russia], in Pashuto, ed., Obshchestvo i gosudarstvo v feodal'noi Rossii: Sbornik statei posviashch. 70letiiu akad. L.V. Cherepnina [State and society in feudal Russia: A collection of articles on the occasion of the seventieth birthday of the academician L.V. Cherepnin] (M.: Nauka, 1975), 6785. Note also that in Lenin's utterance the peasants are defined as a "class" in spite of the orthodox Marxist position.

15. Gary M. Hamburg, Politics of the Russian Nobility, 1881-1905 (New Brunswick: Rutgers University Press, 1984), 5.

16. Vladimir Andrle, A Social History of Twentieth-Century Russia (London: Edward Arnold, 1994), 287-289. 
authoritative, and textbook-like volume Russia. A History, edited by Gregory Freeze, and whose fourteen chapters are written by the best specialists in their respective fields, treats sosloviia as social estates and, to underline the peculiarities of Russia's historical development, the editor writes in the Preface, "Most striking of all, [Russia] only began to construct a system of estates in the eighteenth and nineteenth centuries, as it amalgamated a plethora of tiny service orders into larger estates." 17 But these two examples, which on the face of it seem inadequate with regard to the definition of soslovie, raise the possibility that one (if not the only) sensible meaning of soslovie is indeed "social group," a social group like many others that existed simultaneously in Russian society at that time.

\section{II "Soslovie" and its limitations}

The soslovie was an important part of the realities in Russian society, and so was the estate in the West, but what part of these realities did it represent? What was its role as a factor of stratification? In this regard, it may be useful to indicate some of the limitations and inadequacies of the concept, first, in the history of Russian society; and second, of the estate in the Western European context. In the Russian setting the soslovie concept had three main limitations.

First, large parts of the groups in society were left outside the soslovie system and unaccounted by it. For example, the most important and legal feature of the raznochintsy, about whom Elise Kimerling Wirtschafter has carried out a timely and remarkable research, ${ }^{18}$ was their being nesoslovniki or vnesoslovnye, that is, a non-estate group, "located" outside of the estate system. Nevertheless, the historian M.M. Gromyko defines the raznochintsy as a "soslovnaja gruppa" (a soslovie group). ${ }^{19}$ And in eighteenth-century Siberia, both the authorities and the common folk used the term "soslovie" to designate a group formed primarily from retired military servicemen who became merchants. Another example, not less interesting than the raznochintsy, is that of the trading-peasants residents in the cities; formally they belonged, of course, to the peasant soslovie, but this did not mean much in terms of social realities. At a later stage, this will be the case also with the peasantworkers, and with the industrial proletariat. ${ }^{20}$

17. G.L. Freeze, ed., Russia: A History (Oxford: Oxford University Press, 1997), p. X (my italics).

18. Elise Kimerling Witschafter, Structures of Society: Imperial Russia's "People of Various Ranks"(DeKalb: Northern Illinois University Press, 1994).

19. M.M. Gromyko, "Razvitie Tiumeni kak remeslenno-torgovogo tsentra v XVIII v.," [The development of Tiumen as a crafts and commercial center in the eighteenth century], in N.M. Druzhinin, B.A. Rybakov, V.I. Shunkov, eds, Goroda feodal'noi Rossii: Sbornik statei pamiati N.V. Ustiugova [The cities in feudal Russia: A collection of articles in the memory of N.V. Ustiugov] (M.: Nauka, 1966), 397-398.

20. For an attempt to organize the workers into a soslovie-like framework, see Madhavan K. Palat, "Casting Workers as an Estate in Late Imperial Russia," Kritika, 8, 2 (Spring 2007): 307-348. 
The second limitation is that in some cases soslovie refers or is applied to social groups which even without the soslovie system had always had a very clear social configuration, and their being declared a soslovie did not add much to their internal structure and social functions. The best example of this case is of course the clergy. Another group in this category is the peasantry, which remained impervious to the soslovie-system constructions from the point of view of social realities and not of minute legal distinctions. With the soslovie system or without it, the peasantry was and remained a well-defined social group, bearing its own social articulations and specific ethos (mir, pozemel'naia obshchina, krugovaia poruka, obychnoe pravo), and had an established place in the wider society and its relations with the other social groups. Its structure and social functions remained comparable to peasantries in other countries where sosloviia (estates) had never existed.

As a social group, the peasantry was stronger than, and above, the soslovie system; it had existed before the soslovie system, and continued to exist after it. Similarly, the divide of the peasantry before 1861 between serfs and non-serfs was also unrelated to the soslovie system, and serfdom may have (and had) existed without any kind of estate system. In this regard, it is interesting to give one example of the confusion concerning the peasantry. Thus, referring to the early twentieth century, Gregory Freeze writes:

[...] the soslovie system remained entrenched in the outlook of traditional groups, especially the nobility, and still more the peasantry [...] [T] he peasantry was by far the most rigid, separate, and distinctive component in the whole social order, in good measure because of their strict segregation from the rest of the administrative, judicial, and economic system. ${ }^{21}$

I will set aside the myth of the peasantry's "segregation," suffice it to say that the peasantry did represent a distinct component in the "social order." However, this had nothing to do with the soslovie system. And the soslovie system had nothing to do with the peasantry's "outlook." It seems that in this kind of reasoning the cart is put before the horses, i.e. the cause is taken for the result. Freeze seems to believe that it is the soslovie and the "soslovie outlook" that made the peasantry a rigid social group, whereas, in fact, it was its internal cohesion, agrarian social structure, common customs, and way of life of the peasantry as a social group that make it seem as a "rigid" soslovie. Would the peasantry have been different without the existence of the soslovie system? It does not seem so. ${ }^{22}$

Lack of a clear view of rural Russia generates sometimes historical oversights. For three hundred years, from the early seventeenth century to 1914, a succession of jacqueries - Bolotnikov's in 1606-1607, Stenka Razin's in 1670-1671, Bulavin's

21. Freeze, "The Soslovie Paradigm,” 30.

22. Freeze writes also (p. 27): "the peasantry [...] was treated as a separate subsociety and given its own courts, customary law, and system of administration." Was treated? Was given its customary law? Those are not very felicitous expressions. Moreover, sociologically and anthropologically speaking, the peasantry was a subsociety. Those who "treated" the peasantry as such knew maybe some truths about it worthy of attention. 
in 1707-1708, Pugachev's in 1773-1774 - and from the reforms of Peter I to those of Peter Stolypin, the Russian peasants were fighting for zemlia $i$ volia, for land and liberty, as "rebels in the name of the tsar," which meant also that they were fighting for the tsar and against various forms of the soslovie system. ${ }^{23}$ How come, then, that after these three hundred years of endemic peasant unrest, suddenly "the soslovie system remained entrenched in [their] outlook"? For the period under consideration (c.1900-1914), this may be due to a confusion between the political rhetoric of the peasants and of their representatives, and the social meaning of their rhetoric. In their public utterances they call themselves "krest'ianskoe soslovie" [peasant estate], using a more convenient and accepted expression than "peasant social group." From the point of view of their political rhetoric in the Duma and elsewhere in public, "krest ianskoe soslovie" sounded better than "krest'ianskii mir" [peasant world] since mir could have been understood as "peasant village assembly," or "krest'ianskii klass" [peasant class], which had undesirable Marxist undertones. "Krest ianskoe soslovie" sounded better because it had the respectability of an old, traditional, and officially recognized Russian term. Inversely, the political rhetoric of the noblemen at that time tried to avoid the use of soslovie in order to present their interest not as a particularistic one, but as the general interest of the people and the state.

Furthermore, during that same period (the end of the nineteenth century and the beginning of the twentieth) there is in the spoken and written language (including official documents) a widespread use of the term "soslovie" to designate various groups that are definitely not "estates" as we currently conceive them, like "uchennoe soslovie" (learned estate), "kazatskoe soslovie" (the Cossack estate, in fact, the only one legally recognized as such), and "biurokraticheskoe soslovie"(administrative estate). Similarly, nationalities (of all things) are often referred to as soslovie or sostoianie: "evreiskoe soslovie" [the Jewish estate]. Elise Kimerling Wirtschafter notes that "before emancipation, physicians constituted a distinct, official medical category (soslovie)," 24 and Nancy Frieden indicates that after the Great Reforms the medical profession was defined as a soslovie.25 The 1892 Collection of Laws stipulates that the Estate of Town-dwellers (gorodskoe soslovie) is subdivided into four status groups (sostoianiia): honored citizens, merchants, petty townspeople (meshchanstvo), and artisans (remeslennoe soslovie). Thomas Owen considers all these categories to be estates. ${ }^{26}$ The examples of this wide, indiscriminate, and nonspecific use of "soslovie" abound, although Freeze believes that he found one case (buried in a footnote) that departs from the supposed orthodox meaning. He writes:

23. Daniel Field, Rebels in the Name of the Tsar (Boston: Houghton Mifflin, 1976).

24. Elise Kimerling Wirschafter, Social Identity in Imperial Russia (DeKalb: Northern Illinois University Press, 1997), 88.

25. Nancy Mandelker Frieden, Russian Physicians in an Era of Reform and Revolution, 18561905 (Princeton: Princeton University Press, 1981): 327.

26. Thomas Owen, Capitalism and Politics in Russia: A Social History of the Moscow Merchants (Cambridge: Cambridge University Press, 2008), 2. 
"The most striking exception [from other scholars' view at that time on the nature of sosloviia] is Kliuchevskii [1841-1911], who used soslovie in the elastic sense of 'social category' and applied it to all periods of Russian history, from Kievan Rus' to the nineteenth century." 27 Kliuchevskii, a historian, a teacher, and the author of Istoriia soslovii $v$ Rossii (1887), knew the importance of words and of terms in history as well as in everyday speech. The "elastic sense" was apparently common usage, or else why should he use a term in a way that was opposed to common usage and risk thereby to be misunderstood by his readers and listeners? The answer is simple: far from being an "exception," Kliuchevskii's use reflected the current one, and everyone understood him perfectly well. Soslovie was first and foremost a social category, much more than anything else.

The third limitation of the soslovie system and of the soslovie concept lies in that the soslovie (all the sosloviia) included always a variety of social groups (sometimes even conflicting social groups). The preeminent example is of course the nobility, and in a certain sense it is also a crucial one because when we speak of the soslovie system, we think mainly (although implicitly) of the nobility and in terms of the nobility. Thus, Haimson writes that in the early twentieth century the soslovie system remained largely intact in consciousness and law, even as the sosloviia reconceptualized as kul'turno-bytovye gruppy - that is, social groups defined by their subculture and peculiar life styles. ${ }^{28}$ This is correct and, as Haimson points out, "the spokesmen of the provincial landed nobility now frequently used in preference to soslovie the term kul'turno-bytovaia gruppa." However, this expression does not represent a "reconceptualization" of the soslovie system, but the choice of a term for self-identification by a given group within the nobility, and its use in the group's political rhetoric This terminology cannot be projected to the whole of the soslovie system, for it is a restrictive and exclusive one, which, strictly speaking, indicates a (provincial) kul'turno-bytovaia gruppa, different, say, from the city nobility. The choice of this terminology indicates also (indirectly) that in the early twentieth century the soslovie system was disintegrating and not gaining in strength and prestige.

Even if the "soslovie paradigm" fitted perfectly well the nobility (which it did not do anyway), one thing seems clear: the nobility cannot be equated with the whole of Russian society and the other social groups within it. The "soslovie paradigm" did not fit well the nobility because the dvorianskoe soslovie included all the noblemen (hereditary and personal nobles alike) in spite of the considerable legal discrepancies in status and privileges between these two major categories. In terms of social realities, the contrast was even greater. ${ }^{29}$ Daniel Field writes (for the first half of the nineteenth century, and more precisely the

27. Freeze, "The Soslovie Paradigm," 12 , note 7.

28. Haimson, "Conclusion," 276.

29. On several of the topics discussed here see the excellent collection of articles Noblesse, État et Société en Russie: XVI -début du XIXe siècle, a special issue of Cahiers du Monde russe, 34, 1-2 (January-June 1993). 
years 1833-1857): “...when contemporaries spoke of 'the nobility' they usually meant the serfholders, ignoring the legal demarcation of the estate. Nobles without serfs were not thought to have a common interest with the rest of the nobility, and were excluded by law from participating in the corporate institutions of their estate." 30 Seymour Becker remarks: "Although it was never legally defined as a landed estate, the nobility was widely perceived as such." 31 Landless nobles were not considered as belonging to the soslovie. And Richard Pipes observes: "the dvorianstvo was indeed a landed estate in the sense that prior to Emancipation it owned nearly all the privately held, cultivated land of the empire." 32 In spite of the apparent rigidity of the soslovie, there existed a cleavage within the nobility between landowners and landless nobles, as well as between serf-owners and non-serf-owners: the possession of land and serfs mattered more that the legal definitions of the estate.

That was one crack in the unity of the soslovie. There were more. Referring to the first half of the nineteenth century, Hans-Joachim Torke writes: "Ennoblement was no longer important, or, in other words, even a nobleman was nobody without a rank." 33 But it appears that rank was not enough either. Thus, Gary Hamburg says: "Respect did not automatically attach, for example, to a person named Prince Golitsyn, everything depended on whether the prince was rich or poor." 34 One may ask therefore, what kind of estate was that and what kind of estate society? Part of the answer may be found in the following description of Daniel Field:

"Real noble status was not a matter of gentle birth or past services to the fatherland, it was a function of rank and serfholding. Those who held many serfs and had at least been blooded in the service of the state were full-fledged noblemen, those who held a modest number of serfs were equivocally noble, while the unfortunates who had few serfs or none, even though heroes of 1812 or descendants of Riurik, were effectively excluded from the noble estate [...] [The Russian nobility], whether considered as a legally defined status, or,

30. Daniel Field, The End of Serfdom: Nobility and Bureaucracy in Russia, 1855-1861 (Cambridge: Harvard University Press, 1976): 10; at a later stage, noblemen who owned less than 100 serfs were also excluded from participating in the institutions of the noble estate.

31. Becker, Nobility and Privilege, XIV.

32. Richard Pipes, Russia under the Old Regime (London: Weidenfeld and Nicolson, 1974), 179.

33. Hans-Joachim Torke, "Continuity and Change in the Relations between Bureaucracy and Society in Russia, 1613-1861," Canadian Slavic Studies, 5 (1971): 467. (A literary example of a person who, though of high birth, did not count in society is Prince Myshkin in Dostoevskii's Idiot.)

34. Hamburg, Politics of the Russian Nobility, 15. A similar situation existed in England too in the eighteenth century: "What one notices about it first of all is the importance of money. The landed gentry are graded not by birth or other marks of status but by rentals: they are worth so many thousand pounds a year. Among the aristocracy and ambitious gentry, courtship is conducted by fathers and by their lawyers, who guide it carefully towards its consummation, the well-drawn marriage settlement." (E.P. Thompson, "Eighteenth-century English Society: Class Struggle without Class?," Social History 3, 2 (May 1978): 138.) 
more realistically, in terms of the franchise law [...] was divided within itself." 35

Divided it was indeed, and in more than one respect, and this characteristic makes even more limited the scope of the legal definition of "estate." Actually, what characterized the nobility as a soslovie was, contrary to Freeze's view, a long process of internal disintegration as a result of which the internal cohesion of the nobility broke down in the nineteenth century, and subgroups emerged which made the notion of "soslovie" almost meaningless, and this was so from top to bottom: from the one thousand families of the grandees - the Sheremetevy, the Golitsyny, the Iusupovy-down to the paupers described by Gogol. On the eve of the Emancipation 44 percent of the serf-owners held only 3.3 percent of the serfs, and were in a state of sheer poverty, while 3.6 percent of the pomeshchiki owned 43.6 percent of the serfs. In the eighteenth century the picture was not very different. In 1777, 59 percent of the pomeshchiki owned less than 20 serfs (including 32 percent who had fewer than 10 serfs), 2 percent owned between 501 to 1000 serfs, and only 1 percent owned more that 1001 serfs, and even these serf-holders could not be considered as really wealthy, except for the magnates, like the Sheremetevy, who possessed thousands of serfs. ${ }^{36}$ A Government report of 1843 indicated that 9,287 nobles (the majority in the gubernii of Smolensk, Riazan', Simbirsk, Kaluga, and Vologda) had little land, no serfs, and a style of life "virtually indistinguishable from the peasantry." It may be inferred from these descriptions that the noble estate (dvorianskoe soslovie) was never a coherent social group, but a conglomerate of social groups. ${ }^{37}$

The soslovie system was superimposed therefore partially on the real society, which was also characterized by very porous social boundaries. A description of Minister of Education K.A. Lieven (in connection with a proposal of school curricula for special social categories) made him write in 1828 :

In states where social categories (sostoianiia) are strictly separated from one another; where movement from one another, in particular from the middling into the noble, is extremely difficult and very rarely occurs; [in states] that grant nobility only [as a reward] for lengthy and superior services - in such states... it is very easy to introduce such an order [i.e., the organization of education on the basis of social origin]. But in Russia, where there is no middle category or

35. Field, End of Serfdom, 19; the "legally defined status" to which Field alludes is Article 15 of the 1785 Charter of the Nobility, in Svod zakonov Rossiiskoi Imperii, t. 9. Among the families of the nobility who considered themselves descendants of Riurik were the Romodanovskiis, Dolgorukiis, Obolenskiis, Gorchakovs, Shakhovskois, Shcherbatovs, and Tatishchevs.

36. See Michael Confino, "Histoire et psychologie. À propos de la noblesse russe au XVIII siècle," Annales, E.S.C., 22, 6 (November-December 1967): 1163-1205; see also Jerome Blum, Lord and Peasant in Russia from the Ninth to the Nineteenth Century (Princeton: Princeton University Press, 1961), chap. 19: "Rich Noble, Poor Noble," 367-385; Arcadius Kahan, "The Costs of 'Westernization' in Russia: The Gentry and the Economy in the Eighteenth Century," Slavic Review, 25, 1 (March 1966): 40-66.

37. See Jean-Louis van Regemorter, Le déclin du servage, 1796-1855 (P.: Hatier, 1971). 
citizenry; where only the merchant soslovie in some fashion represents such [a category]; where artisans are in all respects equal to farmers and almost always corrupt; where a prosperous peasant can in any time become a merchant, and often is both together; where the extent of the noble soslovie is so boundless that at one end it touches the foot of the throne and at the other is almost lost in the peasantry; where every year many [persons] from the urban and peasant sosloviia enter the nobility after receiving officer rank in military or civil service - in Russia such an arrangement of schools is difficult. ${ }^{38}$

Three main conclusions may be drawn at this point. First, that "the growing complexity within individual sosloviia" (Freeze) began not after 1861, and certainly not in the early twentieth century, but existed quite earlier, and in fact was concomitant to the existence of the sosloviia themselves. At least two estates - the nobility and the townsmen-always included different (sometimes even antagonistic) social groups. Second, that the groups called "sosloviia" did not encompass the totality of the social groups in Russian society, and did not reflect all the varieties of social groups and the differences between them, and last but not least, fragments of the sosloviia were social groups themselves, along other social groups, whether included or not in other sosloviia. Third, that, consequently, the concept (the "paradigm") of soslovie as a tool of social analysis is inadequate and insufficient for imperial Russian society at any time. Even at the "height" of the evolution of the sosloviia-whether the "height" is considered to have happened in the eighteenth century or (like Freeze) at the beginning of the twentieth. If so, the question is: what is the explanatory value of "soslovie" even as a working hypothesis?

In view of these inadequacies it may be inferred that they represent an additional evidence that Russia did not have "genuine" estates like those in the West, as Rieber and Raeff argue, and that these blemishes strengthen the thesis of Russia's uniqueness and peculiar development. This view deserves a careful examination.

\section{Estates in the West and their insufficiencies}

In a discussion in the pages of the Slavic Review in 1982, Marc Raeff wrote that Russia did not have genuine estates and that it "did not develop in time a genuine Ständestaat." 39 To this statement, a participant in the discussion, Isabel de Madariaga, retorted: "[...] do not the absolute monarchs of the late seventeenth century [in the West] end up creating the Ständestaat without the Stände?"40 They did, and this is one case in which Ständestaat developed not only without "genuine" Stände, but without Stände at all. This particularity of Western European development raises the question: could Russia develop "genuine" estates, that is,

38. Quoted in Kimerling Wirtschafter, Social Identity, 67.

39. Marc Raeff, "Seventeenth-Century Europe in Eighteenth-Century Russia? (Pour prendre congé du dix-huitième siècle russe)," Slavic Review, 41, 4 (Winter 1982): 618-619.

40. Isabel de Madariaga, "Sisters under the Skin,” Slavic Review, 41, 4 (Winter 1982): 624. 
estates along the so-called Western European model? Maybe it could if at least such an institution as "genuine estates" did exist at all. In England, for instance, the accepted view was that an estate, an order, or a class are bodies that should have a definite place as such in the body politic. The phrase "the three estates of the realm" survived till the late nineteenth century but to most Britons it conveyed no clear meaning. The erroneous conception arose early (and was current among popular lawyers in the seventeenth century), and held that the "three estates" were king, lords, and commons. The phrase "three estates" as applied to the English constitution in the twentieth century was misleading, and was usually understood of as the lords spiritual, the lords temporal and the commons. England is therefore not part of our purview, since estates did not exist there from the point of view of this discussion. We will see later how matters stood in France, the classic example of a country of estates under the Old Regime.

In order to be meaningful the notion of "estate" should be not only a legal concept but also a concept of social stratification (or else, it becomes a museum's artifact). This is precisely the most important point in Mousnier's model, who understood that very well, and according to whom a stratification by orders or estates is one in which "the social groups [orders or estates] are hierarchized in principle $[. .$.$] according to the esteem, honour and dignity which society attaches to$ particular social functions - social functions which may not have any relation to the production of material goods." 41 According to this definition soslovie is not a genuine estate, but according to that same definition none of the West European estates were "estates" either. Mousnier saw that perfectly well, too, and for that reason, even when dealing with France (the "country of classic estates"), he decided to substitute the concept of "order" to the usual term "états." Mousnier found that conceptually and analytically "états" (estates) were too vague and inadequate, and in his view they were not genuine orders. ${ }^{42}$

However, it turns out that the concept of "orders" is not less vague and inadequate as a scale, a grid, or a model of social stratification. In an important work by François Bluche and Jean-François Solnon, La véritable hiérarchie sociale de l'ancienne France, the authors, using the state tariff rates of the capitation tax of $1695,{ }^{43}$ succeeded to reconstruct horizontally as well as vertically the social hierarchy of the kingdom of France under Louis XIV according to four criteria: dignity, power, wealth, and consideration. Thus they obtained a sensitive Table of Ranks - in their words: Tableau des rangs (sociaux) - comprising 22 ranks

41. Roland Mousnier, Jean-Pierre Labatut, Yves Durand, Problèmes de stratification sociale: deux cahiers de la noblesse pour les États Généraux de 1649-1651 (P.: PUF, 1965): 18. Thus, for instance, according to the Tarif de la capitation of 1695 (see note 43) the lowest army officer had a higher rank than the highest merchant.

42. See also Antonio Domínguez Ortiz, Las clases privilegiadas en la España del Antiguo Régimen (Madrid: Ediciones ISTMO, 1973), and in particular the sections on "El estamento nobiliario."

43. François Bluche and Jean-François Solnon, La véritable hiérarchie sociale de l'ancienne France: Le tarif de la première capitation (1695) (Geneva: Droz, 1983). The capitation was a war tax paid also by the nobility which was exempted from the taille but not from the capitation. 
(catégories) subdivided into 569 levels (niveaux), with an average of 25-26 levels in each rank. These levels cover the whole society of the Ancien Régime gently down the scale from the Dauphin (the heir apparent to the throne) at the top to foreign sailors at the bottom.

This grid of social stratification shows that not only the boundaries between the nobility and the Third Estate were not insuperable, but (as Prince K.A. Lieven wrote about Russia) that there was an integration and interpenetration between the estates. In a society of orders, as Mousnier conceived it, the first upper levels should have been reserved to the nobility; in fact, in the Véritable hiérarchie, the commoners (roturiers) represent 35 percent of the first rank, the highest one, side by side with State Ministers and above the Maréchaux de France (the highest military rank in the realm) and the Dukes (both of them in the second rank). And only in rank seven were to be found the marquis, counts, viscounts, and barons; this, in addition to the interesting fact that there are noblemen even at the twenty-second rank, the lowest one.

If so, what is, then, the society of orders? What are the estates? And what are the "genuine" estates? And if the estates in France were not genuine, how could they exist in Russia? The Table of Ranks of Louis XIV's treasury clercs shows also that the "orders" are a fiction. And the informed conclusion of Bluche and Solnon is: "This society is neither a superimposition of classes, nor a scale of orders." 44 In other words, Mousnier's model of a society of orders does not do justice to the richness and variety of social groups and subgroups in the society of the Old Regime. Is the notion of "class" more helpful?

\section{Sosloviia and classes}

Classes, a vast and complex subject, should be examined briefly in this discussion because of two reasons. ${ }^{45}$ The first is the thesis that sosloviia evolved into classes, which begs the question about the nature of this transformation and of its end product. The second is the view that, in Russia, these classes were not genuine classes, and if so we should clarify what a "genuine" class is, and when it is not a "genuine" one. Actually, this view posits that the social formations that obtained from the sosloviia were not classes like in the West, and consequently a society of classes (or a class society) did not develop in Russia out of the society of estates: thus "bastard sosloviia" led to "bastard classes." What does that mean in terms of social analysis?

The answer to this question is not easy because scholars rarely indicate in what sense they use the term "class." As a consequence, it may be useful to present even

44. Bluche and Solnon, La véritable hiérarchie, 63; and see also the comprehensive Tableau des rangs, 135-203.

45. The literature on "class" and related issues is immense; and since I don't intend to carry out a thorough analysis of this issue, but raise only some open questions, I indicate here some important and useful works. 
briefly several possible meanings of the term in order to better understand the various interpretations. There is, first, the Marxian, or classic Marxist, definition according to which class is determined by the position of a social group toward the means of production and the social relations of production. Such a definition is used, for instance, by Terry Cox in his book Peasants, Class, and Capitalism: "Classes are thus groups which have different positions in the process [of] production and in the expropriation of the surplus product." 46 As a tool of historical analysis, this highly abstract definition of class is as helpful as Arnold Toynbee's model of the succession of the great civilizations for the understanding of Iberian or Balkan history. In any case to assert, in the light of this definition, that the "feudal" class existed in Russia from the ninth to the nineteenth century is not very enlightening; and to assume that classes of that kind evolved out of the sosloviia after 1861 is meaningless.

Because of this shortcoming of the orthodox Marxist definition, neo-Marxists have tried to work out some more dynamic and more historical-oriented definition of "class." Thus, E.P. Thompson has proposed a different one. First, he has denied that class is purely or even primarily an economic category, but rather a living relationship created through acts of will, a living relationship characterized by deep historical ties or a common Weltanschauung. In his words: "Class is defined by men as they live their own history, and in the end this is its only definition." And also: "We know about class because people have repeatedly behaved in class ways." Finally: "All this squalid mess around us (whether sociological positivism or Marxist-structuralist idealism) is the consequence of the prior error: that classes exist, independent of historical relationship and struggle, and that they struggle because they exist rather than coming into existence out of that struggle." 47 But according to this definition, classes have never existed, neither in Russia nor in the West. Thompson was aware of the difficulties that this definition creates, and this awareness led him to the view (a paradoxical one for a neo-Marxist) that classes, as Mousnier believed, have not existed before the rise of capitalism. Thus, an article of his, quoted above, is suggestively entitled: "Eighteenth-century English society: class struggle without class?"48

These definitions may be, then, briefly summarized. In its orthodox Marxist version, "class" has never existed as a social formation and as a tangible reality. For the purpose of social analysis it is a fiction, or, in other words, a highly abstract notion referring to nonexistent entities in actual societies. The neo-Marxist definition (like Thompson's) is too narrow, and the requirement that "class be characterized by 'deep historical ties"" or "common Weltanschauung" makes of the class an almost

46. Terry Cox, Peasants, Class, and Capitalism: The Rural Research of L.N. Kritsman and his School (Oxford: Oxford University Press, 1986); Teodor Shanin, The Awkward Class: Political Sociology of Peasantry in a Developing Society, Russia 1910-1925 (Oxford: Oxford University Press), 26.

47. Thompson, "Eighteenth-Century English Society: Class...": 146, 147, 149 (emphasis in the original)

48. Ibid. 
exclusive club, not a real social formation. It follows that both are of no use as notions of social stratification and of social mobility. This summary indicates also that there is a methodological and taxonomic problem in Marxist thinking and in historical analysis in general. Consequently, it is worth examining briefly two ancillary questions: First, what was the historical origin of the term? Second, what exactly Marx did leave to his disciples regarding the nature of "classes"?

\section{Origins of the term "class"}

Like the origins of many modern concepts and notions, the story of "class" goes back to the French Revolution, which, as is well known, abolished the estates in 1789 , and abolished also the use of the term "estates." After this revolutionary change contemporary jurists began to say: Les États ayant été abolis, nous les dénommons classes [...] La notion de classe a remplacé celle d'État [The estates having been abolished, we call them classes [...] The notion of class has replaced that of estate]. Thus the term "class" came into usage as a linguistic convenience, and not because social classes were born overnight during the French Revolution, and as a result of a political upheaval and not of sociological analysis that uncovered the existence of classes. From that time on the term entered the nineteenth-century French vocabulary with a rather vague and undefined meaning. It was frequently used by the French historians during the Restoration, and became also part of the theoretical metaphysics of social and political thinkers and propagandists from Babeuf to Proudhon, through Fourier, Saint-Simon, Considérant, Enfantin, and also treatises of liberal and socialist thought. Examples of frequent usage are: classes populaires, classes laborieuses, classes bourgeoises (subdivided into haute, moyenne, and petite bourgeoisie). ${ }^{49}$ Some authors, like Louis Blanc and Proudhon, held that there are only two classes: the rich and the poor (or the haves and the havenots), an idea which infuriated Marx.

The French usage spilled into England, where the word "class" was in use since the early seventeenth century, and the most frequent terms in the nineteenth century were privileged classes, high classes, middling classes, low classes, and laboring classes.

\section{Meanings of "class"}

Marx's writings appeared within this lexicological and semantic environment. According to conventional wisdom, his theory came and put order in this linguistic and sociological mess. What did Marx say and what did he leave to his disciples in

49. An utterance of Saint-Simon may serve as an example of the very flexible meaning of the word; he denounced lawyers and metaphysicians as "bastard classes" who sold their services to the highest bidder; F.E. Manuel, The New World of Henri Saint-Simon (Cambridge: Harvard University Press, 1956), 266-267. 
this respect? Here is Eric Olin Wright's succinct analysis: "As has frequently been remarked and bemoaned, Marx never systematically defined and elaborated the concept of class, in spite of the centrality of that concept in his work. To the perpetual frustration of people who seek in the texts of Marx authoritative answers to theoretical problems, in the one place where he promises such an elaboration," the elaboration is missing. This place is the final chapter of Capital (chapter 52), volume 3, entitled "Classes," but the text stops after only one page. Just before the end to this incomplete text Marx wrote: "The first question to be answered is this: What constitutes a class?" Two short paragraphs later comes Engels' sad comment: "Here the manuscript breaks off." 50 Marxist authors point out that although Marx never systematically answered this question, his work is filled with class analysis. And they assert that, with some exceptions, most of Marx's work revolves around two problems: the elaboration of abstract structural schemes of class relations, and the analysis of concrete conjunctural situations of classes as actors. This may be so, nonetheless the answer to the question "What constitutes a class?" was left to posterity and had to be inferred from Marx's writings and the contexts of the word, which were not always clear because of discrepancies between Marx's economic writings and his historical-political ones like, for instance, The Eighteenth Brumaire of Louis Bonaparte, where he says that in so far as millions of families live under economic conditions of existence that separate their mode of life, their interests and their culture from those of other classes, and put them in hostile opposition to the latter, they form a class. In so far as there is merely a local interconnection among them, and the identity of their interests begets no community, no national bond and no political organization among them, they do not form a class: ${ }^{51}$ a most perplexing utterance.

As for the other meanings of "class," the most widely used among scholars, nonMarxists and some Marxists too, is "class" as a descriptive category, not as an analytical one, nor as a conceptual model. In these cases it is (like soslovie) an equivalent of "social groups." Such uses are, for instance, the expressions upper classes, middle classes, lower classes, and also the ruling class (whatever this may mean), the governing class, the business and professional classes, the managerial class. Good examples of this use are an article of Marc Bloch entitled "Les 'colliberti' : étude sur la formation de la classe servile" 52 ; and Louis Chevalier's book Laboring Classes and Dangerous Classes in Paris in the First Half of the Nineteenth Century. In Russian historiography, some scholars use "class" as an

50. Eric Olin Wright, Classes (Norfolk: The Thatford Press, 1985), 6; see also Calvert, The Concept of Class, 11. For an interesting attempt to "reconstruct" the unwritten chapter on "Classes," see Ralf Dahrendorf, Class and Class Conflict in Industrial Society (London: Routledge and Kegan Paul, 1959), 9-18.

51. K. Marx, The Eighteenth Brumaire of Louis Bonaparte (Charleston SC: Bibliobazaar, 2007).

52. "Marc Bloch, Mélanges historiques, vol. 1 (P.: S.E.V.P.E.N., 1963), 385-451. 
equivalent of "estate," 53 in which cases both words mean "social groups." If this is so, and if "class" is used as an equivalent of "social group," then two questions are in order. Is not "class" a misnomer, and is it not a misleading one? To a certain degree it is, and the reasons to keep using are practical and not substantial. Thus, Seymour Becker writes: "Modern society is commonly characterized as "class society' in deference to what are usually considered its most important social formations. The term 'class society' is too well established to be abandoned at this late date, but two precautions should be born in mind. Class is only one and often not the most important basis of social differentiation in modern society [...]"54 And Lenore O'Boyle frankly observes: "To eliminate the word 'class' from the historical vocabulary might be helpful, but is scarcely possible and hardly necessary." 55

Ironically, maybe for lack of a better solution (which always may be forthcoming), should we also say that although not well defined and not entirely clear, the term "soslovie" is too well established in the historians' vocabulary to be abandoned at this late date?

\section{Tel Aviv University, Department of History}

mconfino@post.tau.ac.il

53. For example, see Andrle, A Social History, quoted above; Peter Kolchin, Unfree Labor: American Slavery and Russian Serfdom (Cambridge: Harvard University Press, 1987), 39-40. 54. Becker, Nobility and Privilege, note 4, 196.

55. Lenore O'Boyle, "The Classless Society: Comment on [Peter] Stearns," Comparative Studies in Society and History, 21, 3 (July 1979): 412; see also Peter Stearns, "Reply," Ibid.: 414-415. 